ELEMEN ESTETIS KOREOGRAFI TARI CANG-CANG DI KAYUAGUNG KABUPATEN OGAN KOMERING ILIR

Emy Admala Yuliarti

KONSEP KEBERSAMAAN DALAM TRADISI MIDANG MABANG HANDAK PADA MASYRAKAT MORGESIWE KECAMATAN KAYUAGUNG

A. Heryanto

PANGLIMA LAOQT SEBAGAI LOCAL WISDOM MASYARAKAT NELAYAN PESISIR ACEH (STUDI KASUS TENTANG PANGLIMA LAOQT LHOK KECAMATAN SERUWAY KABUPATEN ACEH TAMIANG)

Purnama Sari \& Puspitawati

PENERAPAN MODEL PEMBELAJARAN COURSE REVIEW HORAY TERHADAP KEMAMPUAN MENJELASKAN ALUR CERPEN UNTUK ANAK SDN 52 PALEMBANG Sri Wahyu indrawati

PENGARUH MODEL PEMBELAJARAN ARTIKULASI TERHADAP KEMAMPUAN MENULIS PADA SMP NEGERI 2 PALEMBANG

Yus Vernandes Uzer

PENGARUH MODEL PEMBELAJARAN COMPLETE SENTENCE TERHADAP KEMAMPUAN MENULIS PADA SMP NEGERI 13 PALEMBANG

Yuspar Uzer

$60-70$

PENGARUH MUSIK ANSAMBEL TERHADAP KECERDASAN EMOSI REMAJA

Novdaly Fillamenta \& Mohammad Arfani

PEWAISAN RABAB PIAMAN DI KECAMATAN LUBUK ALUNG

KABUPTEN PADANG PARIAMAN

Irfan Kurniawan

$82-93$

ESTETIKA MOTIF NAGO BESAUNG PADA KAIN SONGKET PALEMBANG Decky Kunian

BENTUK GERAK TARI KAIN DI SANGGAR DEWAN KESENIAN MUSI RAWAS

Pransiska Sepriyanti 


\title{
BENTUK GERAK TARI KAIN DI SANGGAR DEWAN KESENIAN MUSI RAWAS
}

\author{
Oleh : \\ Pransiska Sepriyanti \\ (Praktisi Tari Kabupaten Musi Rawas)
}

\begin{abstract}
Abstrak
Penelitian ini dilakukan untuk mengetahui bagaimanakah bentuk gerak tari Kain di Sanggar Dewan Kesenian Musi Rawas Kabupaten Musi Rawas dengan menggunakan teori prinsip bentuk dari Sumandiyo Hadi yang berisi tujuh prinsip bentuk gerak. Metode penelitian yang digunakan oleh peneliti adalah metode kualitatif yang terdiri dari teknik observasi, wawancara dan dokumentasi dalam mengumpulkan data mengenai bentuk gerak tari Kain di Sanggar Dewan Kesenian Musi Rawas. Dari hasil penelitian yang di dapat peneliti menyimpulkan bahwa tari Kain adalah tari sambut yang mempunyai makna dimana tradisi masyarakat yang mengistimewakan tamu, dimana tamu Laki-laki yang datang akan diberikan Kain.
\end{abstract}

\section{Kata Kunci : Tari Kain, Bentuk Gerak}

\section{A. PENDAHULUAN}

Setiap daerah atau wilayah memiliki banyak kekayaan salah satunya kebudayaan, Sumatera Selatan menjadi salah satu tempat beragamnya kebudayaan dan memiliki ciri-ciri yang khas di setiap daerah. Sumatra Selatan sendiri terdapat beberapa kota dan beberapa kabupaten. Musi Rawas merupakan salah satu Kabupaten yang ada di Provinsi Sumatera Selatan. Musi Rawas bertepat di ibu Kota Muara Beliti, kebudayaan yang ada di Musi Rawas memegang adat istiadat atau kebiasaan yang ada. Dimana kebudayaan yang ada di wilayah Musi Rawas bergotong royong, bertani dan menjaga kebudayaan-kebudayaan yang ada.

Kebudayaan adalah keseluruhan sistem gagasan, tindakan dan hasil karya manusia dalam rangka kehidupan masyarakat yang dijadikan milik diri manusia dengan belajar. Kebudayaan juga sebagai bagian yang takterpisahkan dalam kehidupan manusia, baik secara individual (Widaryanto, 2011:17)

Menurut Koentjaraningrat (dalam Widaryanto, 2011:18) yang mengatakan bahwa kata kebudayaan berasal dari kata sanskerta buddhayah. Kata buddhayah ini diartikan sebagai budi atau akal yang berasumsi bahawa kebudayaan itu merupakan hasil karya manusia dalam suatu proses yang berkelanjutan sesuai dengan perkembangan akal budi manusia dalam kehidupannya. Dalam hal ini bisa terlihan kebudayaan yang ada di Kabupaten Musi Rawas seperti peninggalan-peninggalan dari zaman nenek moyang, dan kesenian, dalam berkehidupan bermasyarakan kesenian menjadi tempat hiburan bagi setiap individu dan menjadi kebutuhan.

Menurut Herbert Read (dalam Robert, 2017:1) menyebutkan bahwa seni merupakan usaha manusia untuk menciptakan bentuk-bentuk yang menyenangkan. Bentuk-bentuk yang 
menyenangkan dalam arti bentuk yang dapat dibingkai oleh perasaan keindahan dan perasaan keindahan itu dapat terpuaskan, apabila dapat menangkap harmoni dan satu kesatuan dari bentuk yang disajikan. Salah satu seni yang dijadikan sebagai media pengungkapan ekspresi jiwa manusian yaitu seni tari. Fathul A. Husein (dalam Widaryanto, 2004 : xi) Tari merupakan bentuk seni yang bersifat elusif (tak mudah dipahami) dan memiliki lapisan-lapisan simbolis yang tidak jarang sangat pekat, maka kritisisme tari mustahil bisa menyodorkan deskripsi pristiwa yang serba netral kendati secara unik mampu membuat dokumentasi berharga dalam karya seni. Soedarsono (dalam Widaryanto, 2011:7) menerangkan bahwa Tari adalah ekspresi perasaan tentang sesuatu lewat gerak ritmis yang indah yang telah mengalami stilisasi atau distorsi.

Berdasarkan teori diatas tari pada dasarnya sama untuk mengungkapkan perasaan dan jiwa manusia, dan dari zaman kezaman manusia sudah menggunakan tari untuk mengungkapkan perasaan atau isi hatinya kepada Tuhan, dewa-dewa atau para roh leluhur. Tari yang berkembang disuatu wilayah atau masyarakat adalah tari tradisi dimana tari tradisi ini merupakan tarian yang turun secara turuntemurun, bisa juga merupakan tarian yang terbuat oleh kebiasaan atau tradisi masyarakat dengan mengangkat tema tentang kebudyaan daerah sendiri dan dijadikan sebagai identitas suatu dareah.

Sanggar Dewan Kesenian Musi Rawas merupakan salah satu sanggar yang ada di
Kabupaten Musi Rawas. Sanggar Dewan Kesenian Musi rawas merupakan tempat dimana berkumpulnya dan sebagai wadah pencipta dan pekerja seni berkarya. Banyak tarian-tarian yang sudah dikeluarkan pada sanggar Dewan Kesenian Musi Rawas salah satunya yaitu tari Kain, tari Kain merupakan salah satu tarian tradisional yang ada di Kabupaten Musi Rawas tepatnya di Kecamatan Selangit. Tari Kain jugamerupakan salah satu tari Persembahan yang ada di Kabupaten Musi Rawas, tari Kain sendiri untuk awal mula dan asal usulnya tidak diketahui kapan dimana dan siapa penciptanya, karena tari Kain dan tarian tradisi Kabupaten Musi Rawas ini rata-rata sudah berumur lebih dari 90 Tahun, karena tari Kain ini sediri sudah ditarikan sebelum merdeka sudah sering ditarikan. Tari Kain ini biasanya ditarikan untuk menyambut tamu-tamu yang datang disuatu acara, dimana di daerah-daerah dan di dusun-dusun dari dulu hingga sekarang setiap tamu yang datang pasti akan mendapatkan Kain, jadi tari Kain ini dibuat pada waktu itu untuk menyambut Tamu-tamu yang hadir di Kabupaten Musi Rawas. Tari Kain juga dikembangkan di Sanggar Dewan Kesenian Musi Rawas dimana sanggar Dewan Kesenian Musi Rawas sendiri merupakan salah satu sanggar yang ada di Kabupaten Musi Rawas, yang didirikan pada tahun 1991 (Wawancara: Hammam, 18 juli 2019).

Peneliti melihat bahwa bentuk gerak dalam Tari Kainini belum diteliti atau belum ada yang membuatnya dalam bentuk tulisan, bentuk gerak yang mengambil dari gerakan sehari-hari 
masyarakat atau kebiasaan tradisi masyarakat Kabupaten Musi Rawas yang dianggap unik oleh peneliti dan menarik untuk diteliti.

\section{B. METODE PENELITIAN}

Dalam penelitian ini, peneliti menggunakan metode penelitian kualitatif. Metode penelitian kualitatif adalah salah satu penelitian yang bertujuan untuk mendapatkan pemahaman tentang kenyataan memalui proses berfikir induktif (Hotman dan Siahaan, 2002:2). Metode penelitian kualitatif juga merupakan metode penelitian yang digunakan untuk meneliti pada kondisi obyek ynag alamiah, penelitian kualitatif lebih menekankan makna dari ada generalisasi (Sugiyono, 2016:1). Metode deskriptif kualitatif adalah suatu metode dalam pencarian fakta status kelompok manusia, suatu objek, suatu kondisi, suatu sistem pemikiran ataupun suatu peristiwa pada masa sekarang dengan interpretasi yang tepat (Hera dalam Sitakara, 2016:5).

Konsep pengertian mengenai metode penelitian diatas, jadi penelitian kualitatif merupakan metode penelitian yang digunakan untuk mendapatkan suatu pernyataan atau suatu hal yang nyata ataupun fakta dari suatu objek. Dalam penelitian bentuk gerak tari Kain peneliti menggunakan metode penelitian kualittif. Data yang didapatkan akan dianalisis ke dalam bentuk penulisan deskriptif karya ilmiah.

\section{HASIL PENELITIAN DAN PEMBAHASAN}

Penelitian ini bertujuan untuk mengetahui bentuk gerak tari Kain di Sanggar Dewan Kesenian Kabupaten Musi Rawas. Data dikumpulkan melalui beberapa teknik pengumpulan data yakni observasi, wawancara dan dokumentasi.

Kabupaten Musi Rawas salah satu Kabupaten yang memiliki keanekaragaman budaya dan keseniannya yang tumbuh dan berkembang dengan sangat baik. Banyak tari tradisional yang berkembang di Kabupaten Musi Rawas dan berkembang di Sanggar Dewan Kesenian Musi Rawas. Tari Kain sendiri bukti dari kebudayaan daerah Kabupaten Musi Rawas. Tari Kain merupakan tari tradisional yang pada masanya berfungsi untuk menyambut tamu Lakilaki yang datang dan disambut oleh penari Perempuan. Tari Kain saat ini sudah jarang ditarikan karena kurangnya permitaan bahkan tidak ada lagi permintaan dari pemerintah untuk menunjukan eksistensi tari Kain ini. Tari Kain dibawakan oleh satu penari, dimana memang pada masanya tarian ini ditarikan oleh satu orang penari Perempuan untuk menyambut tamu Lakilaki.

Setelah lama tari Kain ini berkembang dan Sanggar Dewan Kebudayaan Musi Rawas mencoba memvariasikan tarian, tari Kain ini bisa ditarikan lebih dari satu orang jika tempatnya memadai, dan pernah juga tarian ini ditarikan oleh dua orang. Mengapa tari Kain ini dikatakan tari Kain karena pada saat pentas penari dalam menyambut tamu itu menggunakan Kain sebagai 
properti dan simbol bahwa setiap tamu yang datang di Kabupaten Musi Rawas ini diberikan Kain, makaitu Kain sendiri menjadi properti atau simbol.

Berdasarkan perwujudan dalam tari adalah gerak, maka peneliti mengambil konsep yang dipakai oleh Y.Sumandiyo Hadi yang berisi prinsip bentuk yaitu kesatuan, variasi, repetisi, transisi, rangkaian, klimaks. Penelitian dalam bentuk gerak tersebut menggunakan metode penelitian deskriptif kualitatif yaitu pengumpulan data yang terkait dengan bentuk gerak tari Kain di Sanggar Dewan Kesenian Musi Rawas.

\section{Kesatuan}

Kesatuan inilah unsur konstruksional yang menyeluruh. Isi gerak sesuai dengan makna dan cara dimana unsur konstruksi menghasilkan bentuk bagian-bagiannya atau keseluruhan. Rangkaian dalam kesatuan suatu kerangka dan juga bentuk kerangka yang pada akhirnya menghasilkan kesatuan (Smith, 1985:75-76). Kesatuan atau unity adalah prinsip yang sangat penting dalam bentuk gerak atau koreografi."kesatuan" mengandung pengertian menjadi satu yang utuh. Kesatuan aspek-aspek gerak, ruang, dan waktu yang hadir dalam tari merupakan keutuhan yang siap di hayati (Hadi, 2007:25). Kesatuan atau unity dapat dipahami bahwa terbentuknya satu bentuk tari karena melibatkan aspek gerak, ruang dan waktu yang pada perwujudannya dihayati dan dimengerti dalam setiap aspeknya (Rochayati Dkk, 2016:48).
Kesatuan pada tari Kain telah menjadi kesatuan yang utuh. Gerakan tari Kain telah menghasilkan rangkaian yang sesuai dengan makna dan isi gerak yang tercipta berdasarkan maksud dan tujuan dari tari Kain diciptakan sehingga tari Kain telah menjadi kesatuan. Letak kesatuan dalam tari Kain dapat dipahami apabila dilihat dan ditelaah dari awal hingga akhir tarian. Meskipun memiliki tempo lambat dan cepat, ritme yang sesuai dengan iringan. Kesatuan atau keutuhan di dalam gerak tari Kain terdiri dari usur gerak, ruang dan waktu. Maka prinsip kesatuan pada tari Kain dapat dilihat dari penjelasan sebagai berikut.

\section{a. Gerak}

Gerak di dalam tari adalah bahasa yang dibentuk menjadi pola-pola gerak dari seorang penari. Prinsip-prinsip bentuk yang perlu dianalisis meliputi antara lain: Kesatuan, variasi, repetisi, atau ulangan, transisi, rangkaian, perbandingan dan klimaks (Hadi, 2007:25). Gerak merupakan media yang paling tua dari manusia, untuk menyatakan keinginan-keinginannya. Jika kita pertahankan, bayi yang baru saja lahir, sebagai bukti bahwa ia menggerakkan beberapa anggota tubuhnya. Gerak merupakan unsur utama dalam tari, maka gerak-gerak yang ditampilkan mengandung maksud atau maknamakna tertentu (Supriantini, 2014:19).Gerak adalah dasar ekspresi. Oleh sebab itu "gerak" kita temui sebagai ekspresi dari semua pengalaman emosional yang diekspresikan lewat medium yakni gerakan tubuh atau gerakan seluruh tubuh (Hadi, 2016:10). 
Perwujudan dalam tari adalah gerak, gerak adalah media komunikasih seorang koreografi atau penari kepada penikmat. Gerak juga merupakan media yang paling penting dalam pengungkapan maksud dan tujuan yang disampaikan penari dalam bentuk geraknya. Pada tari Kain, bentuk gerak tarinya memiliki ciri khas yakni dimana sebagaian besar gerakannya lebih dominan gerakan tangan dan kaki, anggota tubuh lainnya tidak terlalu dominan bergerak. Berikut merupakan uraian bentuk gerak tari Kain : Melayang berdiri, Ngeliuk, Hormat, Melenggok badan kanan, Ngeliuk, Melenggok Badan Kiri, Ngeliuk, Melenggok Kain kana, Ngeliuk, Melenggok kain kiri, Ngeliuk, Nampi kana, Ngeliuk, Nampi kiri, Ngeliuk duduk, Melenggok badan duduk kanan, Melenggok badan duduk kiri, Melenggok kain duduk kana, Melenggok kain kiri, Ngeliuk berdiri, Hormat, Melayang keluar.

b. Ruang

Ruang adalah sesuatu yang tidak bergerak dan diam sampai gerakan yang terjadi didalamnya mengintrodusir waktu, dan dengan cara demikian mewujudkan ruang sebagai suatu bentuk, suatu ekspresi khusus yang berhubungan dengan waktu yang dinamis dari gerakan (Hadi, 2007:25). Ruang yang diciptakan oleh penari adalah ruang yang dibatasi oleh imajinasi penari yang beruap gerak terjauh dan dapat dijangkau oleh tangan dan kakinya dalam posisi tidak berpindah tempat sedangkan ruang pentas adalah ruang arena yang digunakan oleh penari untuk menari (Fitriani, 2018:94).
Ruang dalam tari akan menghasilkan tari yang baik jika ruang tersebut dapat disampaikan dengan baik. Ruang dalam tari terbagi menjadi dua yakni ruang yang dibatasi gerak oleh imajiner penari dan ruang pentas yakni arena yang digunakan penari untuk menari. Ruang yang dibatasi penari dalam tari Kain yakni, gerak sembah dimana berjalan mengibaskan kain tangan kiri dan kanan memegang kain dengan gerakan buka tutup - buka tutup lalu hormat.

B1. Ruang Imajiner

Ruang imajiner penari yaitu gerakan itu sendiri mengandung ruang, dan ruang itu juga ada disekeliling penari yang memungkinkan tubuh dapat bergerak menjangkau atau mewujudkan keruangan, imajiner yang memiliki kesan atau sentuhan emisional yang berbeda-beda (Hadi, 2016:15).

\section{b1.1 Positif dan Negatif}

wujud dari ruang positif adalah keruangan yang ditempati secara nyata oleh obyek atau dalam hal ini desain wujud gerak tari. Sementara ruang negatif adalah keruangan yang kosong atau nihil diantara obyek-obyek atau wujud desain gerak (Hadi, 2016:16). Didalam ruang gerak tari Kain terdapat wujud ruang positif dan negatif ini secara sederhana dan jelas, seperti pada ragam gerak Melayang dimana pada saat tangan direntangkan menunjukan bahwa yang dimaksud dengan wujud ruang positif adalah yang ditempati oleh tubuh penari sedangkan ruang negatif yakitu keruangan yang tidak di tempati oleh tubuh penari atau di sekitar tubuh penari. 


\section{b.1.2 Arah}

Tari Kain terdapat 4 arah hadap yang digunakan dalam ragam gerak yaitu, depan, kanan, kiri, dan putaran. Arah hadap digunakan pada saat pegantian gerak dimana seperti arah hadap kanan dan kiri ditunjukan pada setiap ragam gerak. Melenggok Badan Kanan, dengan arah hadap ke kanan dan Melenggok Badan Kiri, dengan menghadap ke kiri. Gerakan Hormat yang mengarah kedepan dan Ngeliuk dengan menggunakan putaran.

\section{b.1.3 Pola Lantai}

Tari Kain merupakan tari tunggal yang di tarikan oleh satu orang penari Perempuan, dimana pola lantai yang digunakan hanya menggunakan satu pola hanya arah hadapnya saja yang berbeda, hanya ada pada saat penari memasuki tempat pentas dengan gerakan Melayang menuju pentas. maka dari itu didalam tari Kain tidak memiliki pola lantai.

\section{b.1.4 Level}

level yang digunakan dalam tari Kain yakitu menggunakan lever tinggi, sedang dan rendah. Gerakan didalam tari kain yang menggunakan level tinggi yaitu gerak Melayang dimana pada saat tangan direntangkan kedua kaki menyinjit. Gerakan yang menggunakan level sedang yaitu Melenggok Badan, Melenggok Kain, Nampi, dimana pada saat gerakan tersebut posisi tubuh tegak. Sedangkan level rendah dalam tari akin yaitu pada gerak Ngeliuk, dan gerakan duduk.

\section{b.1.5 Dimensi}

Dimensi didalam tari merupakan jarak jangkauan, didalam tari kain yaitu gerak Melayang memiliki jangkauan gerak vertikal karena memiliki janggauan semula di luar pentas sehingga mengarah ke sudut depan pentas.

\section{C1. Ruang Penari atau Ruang Nyata}

Ruang penari atau ruang nyata merupakan area pentas sebagai tempat dimana penari melakukan aktifitas bergeraknya. Ruang yang dibatasi oleh penari dalam tari Kain yakni, gerak Melayang dimana berjalan dengan kedua tangan mengayunyan tangan kesamping dan kedepan dada.

\section{c. Waktu}

Unsur waktu dalam gerak sebagai suatu alat untuk memperkuat hubungan-hubungan kekuatan dari rangkaian gerak, dan juga sebagai alat untuk mengembangkan secara kontinyu, serta mengalirkan secara dinamis, sehingga menambah keteraturan tari. Struktur waktu dalam tari dapat dianalisis adanya aspek-aspek tempo, ritme, dan durasi (Hadi, 2007:70). Waktu adalah elemen yang membentuk gerak tari selain unsur tenaga yang tidak dapat di pisahkan karena merupakan suatu struktur yang saling berkaitan dengan ritme tubuh. Di dalam unsur waktu ada dua faktor yang sangan penting yaitu tempo, dan ritme. Tempo adalah lebih mengara pada kecepatan tubuh penari yang dapat dilihat dari perbedaan panjang dan pendeknya waktu yang diperlukan (Sartono, 2014:21). Ritmi di analisis dalam bentuk gerak merupakan pola hubungan "timbal-balik" atau "perbedaan" dari jarak waktu 
"cepat dan lambat". Pengulangan yang sederhana dengan interval-interval berjarak waktu yang sama, perubahannya yang "ajeng" dan sama (Hadi, 2007:70).

Waktu digunakan dalam menari agar dapat membantu penari memahami ketukan atau dimamika selama menari. Waktu dalam menari diperlukan agar penari mengetahui letak tempo dan ritme pada setiap gerak tari yang ada. Pada tari Kain, pada dasarnya memiliki tempo dan ritme. Tempo yang terdiri dari cepat lambatnya suatu gerakan sedangkan ritme adalah ketukan yang dilakukan sesuai dengan iringan. Dalam tari Kain tempo mengikuti ritme dimana tari Kain sendiri mengikuti suasana lagu.

Kesatuan merupakan hal yang paling penting karena unsur-unsur yang terdapat di dalam tari Kain ini telah menjadi satu kesatuan yang utuh dan tidak dapat dipisahkan antara ragam satu dengan yang lainnya diantaranya gerak, ruang, dan waktu.

\section{Variasi}

Variasi dimaksudkan memberikan kemungkinan peningkatan bahwa isi, yang telah ditetapkan dalam tari digunakan lagi dalam cara yang berbeda. Penata tari harus mempertimbangkan kesempatan isi tetapi hal ini tidak harus dilakukan hanya demi kontras semata-mata (Smith, 1985:69). Variasi adalah prinsip bentuk yang harus ada dalam sebuah tarian atau koreografi, sebagai karya kreatif harus memahami yang serba "baru". Dalam proses pembentukan gerak, perlu memperlihatkan nilainilai kebaruan itu. Prrinsip variasi juga sesungguhnya bukan untuk kepentingan "variasi" itu sendiri, variasi harus berkembang dalam keutuhan atau kesatuan (Hadi, 2007:26). Variasi dalam tari menjadikan tarian lebih hidup dan tidak membosankan. Namun penting juga dipahami bahwa variasi yang di bentuk tetap sejalan dengan konsep dasar dan kebutuhan tariannya.(Rochayati Dkk, 2016:48).

Variasi adalah salah satu prinsip yang sangat penting dan harus dilakukan untuk menghasilkan tarian yang indah dengan menggunakan variasi-variasi gerakan yang indah sehingga tidak membuat tarian tersebut terlihat membosankan. Didalam tari Kain gerak yang termasuk dalam Variasi adalah gerakNgeliuk dan Ngeliuk Duduk. Variasi dalam tari Kain terdapat pada gerakan Ngeliuk dimana pada saat gerakan Ngeliuk itu perputaran $180^{\circ}$ dimana dilakukan dengan berdiri sedangkan Ngeliuk Duduk dimana tubuh berputar $180^{\circ}$ dan diiringin dengan duduk dengan tubuh bertumpuh ditumit kaki yang menjinjit. Variasi yang dilakukan berdasarkan level dari seadang ke level rendah.Variasi dalam tari Kain ini bertujuan untuk membuat gerak tari yang baru dengan tetap menjaga kesatuan gerak yang ada.

\section{Repetisi atau Pengulangan}

Pengulangan semestinya dimengerti sebagai pembagian pokok dalam komposisi tari, pengulangan dapat hadir bentuk pengulangan dan variasi materi gerak yang di tetapkan diantara setiap motif (Smith, 1985:69). Repetisi atau pengulangan yaitu sifat tari yang terjadi dalam waktu yang sesaat. Tanpa adanya 
"pengulangan", suatu tangkapan indrawi penglihatan akan cepat hilang, karena berbaganti dengan tangkapan gerak yang lain. Supaya terlihat kekhasan bentuk koreografi sebaiknya perlu adanya pengulangan (Hadi, 2007:26). Hawkins menegaskan (dalam Hadi,2007:27) bahwa "pengulangan" digunakan dalam pembentukan gerak tari tidak hanya sebagai satu cara penyampaian ide, tetap juga sebagai satu metode memastikan para pengamat berkesempatan untuk menangkap dan menyerap bentuk gerak. Smith (terjemah dalam Rochayati Dkk, 2016:39) mempertegas bahwa kata "pengulangan" berarti sesuatu yang persis sama lagi oleh karena itu gagasan pengulangan sebagai elemen konstruksi perlu di amplikasikan sehingga materi dapat dimanipulasi.

Pengulangan sangat penting didalam tari dan sangat diperlukan mengingat juga sifat tari yang sesaat, yang dibatasi oleh waktu dan akan berakhir setelah pertujukan selesai. Pengulangan juga bermaksud sebagai pengulang kembali gerak yang disampaikan. Dalam konsep pengulangan ada tujuh pengulangan yaitu:

1) Pernyataan kembali atau penuangan kembali secara persis, pelaku gerak tersebut dapat melakukan gerak yang mempunyai kesamaan identitas yang dapat dipentaskan dengan sisi lain tubuhnya.

2) Penguatan kembali - membuat gerak lebih luas, atau menambah perhatian lebih atau mendefinisikan gerak dengan saat diam di tempat.
3) Gema-ulang dimaksudkan bahwa sutu materi yang telah lampau kembali dengan isi baru.

4) Re-kapitulasi berarti bahwa pernyataan terjadi lagi dengan memperpendek atau meneropong isi.

5) Revisi - mengulang kembali beberapa gerak terperinci atau memperjelas bagian tertentu.

6) Mengingat kembali (recall), yaitu mengingatkan kembali yang lampau, pada materi baru penonton diingatkan pada sesuatu yang telah terjadi sebelumnya. Isi boleh jadi tidak sama, tetapi ada ada kemiripan.

7) Mengulangi kembali (reiterate), penekanan fakta pengulangan berlanjut yang makin menghilang/menipis.

Pada tari Kain konsep yang digunakan yaitu, pernyataan kembali atau penuangan kembali secara persis, pelaku gerak tersebut dapat melakukan gerak yang mempunyai kesamaan identitas yang dapat dipentaskan dengan sisi lain tubuhnya. Dalam perlakuaannya motif gerak yang dilakukan pada sisi kanan akan dilakukan pada sisi kiri dan gerakan yang dilakukan berdiri akan dilakukan dengan posisi duduk dalam pola ruang, pola waktu, dan pola tengga yang sama. Seperti gerak, 1. Melenggok Badan Kanan-Kiri, 2. Melenggok Kain Kanan-Kiri, 3. Nampi Kain Kanan-Kiri, 4. Melenggok Badan Duduk Kanan-Kiri, 5. Melenggok Kain Duduk Kanan-Kiri, 6. Melayang. Repetisi atau pengulangan perlu dilakukan karena dengan 
adanya pengulangan dapat membantu penonton mengingat kembali gerakan yang ditampilkan, agar tidak cepat hilang dan bersifat sesaat dapat memahami apa isi dan makna gerak tersebut.

\section{Transisi atau Perpindahan}

Transisi berfungsi melekatkan setiap bagian menjadi satu sebagai jembatan, dan oleh karena itu membantu untuk menciptakan keseluruhan kerangka ritmis (Smith, 1985:73-74). Perpindahan atau transisi memunyai peranan "pengikat" bersama yang sangat penting, dan harus logis, terasa "enak" jelas, sehingga mampu memperlihatkan kelancaran gerakan. Motif gerak transisi tidak dapat berdiri sendiri harus menyatu dalam kesatuan motif-motif gerak yang akan di sambung (Hadi, 2007:27). Transis untuk menyambung seluruh bagian-bagian sehingga secara efektif menciptakan keutuhan keseluruhan (Rochayati Dkk, 2016:43).

Transisi atau biasanya disebut gerak penghubung ini berguna untuk menyatukan tiap ragam gerak yang ada. Seorang penata tari harus memahami bahwa transisi atau perpindahan digunakan untuk menyambungkan dari gerakan satu ke gerakan yang lainnya. Transisi ada karena setiap ragam gerak biasanya disusun secara terpisah atau berdiri sendiri sehingga membutuhkan transisi untuk melakukan setiap ragam gerak yang terpisa.

Peneliti melihat bahwa gerak transisi atau penghubung pada tari Kain juga ditemukan pada saat penari akan melakukan yang baru yakni penari merentangkan kedua tangan dan mengayunkannya ke atas dan ke bawah secara bergantian dan diiringi dengan putaran badan, dengan posisi setengah mendak. Setiap pergantian gerakan selalu diselingi dengan gerakan Ngeliuk sebagai transisi dari setiap gerak. Transisi pada tari Kain ini juga dapat dilihat saat penari memindahkan kain dari ragam gerak satu menuju perubahan ragam gerak berikutnya.

Transisi atau perpindahan di dalam tari Kain ini berguna sebagai penghubung dalam setiap ragam geraknya, dengan adanya transisi atau perpindahan ini maka ragam gerak tari Kain ini mampu dikatakan sebagai satu kesatuan yang utuh.

\section{Rangkaian}

Rangkaian atau pengulangan logis adalah mengacu pada pertumbuhan alami tari sejak awal sampai akhir dan bila sesuatu itu logis maka harus mempunyai makna melaui keberadaannya (Smith, 1985:74-75). Rangkaian adalah salah satu prinsip yang perlu diperhatikan karena bentuk gerak tari dapat dirasakan sebagai satu pengalaman.sebuah tarian atau koreografi baik literal maupun nonliteal bagaikan sebuah kejadian, sehingga eksperi gerak yang diungkapkan secara abstrak adalah pandangan yang sangat dalam dari seorang penari. Oleh sebab itu harus dialami sebagai satu kejadian dari awal sampai akhir (Hadi, 2007:28). Pemahaman tentang rangkaian maka tidak sebatas bagaimana merangkai gerakan yang sudah ada dan tidak terbatas bagaimana gerakan tersebut dapat tersusun dengan rapi. Akan tetapi lebih dari itu (Rochayati Dkk, 2016:51). 
Rangkaian merupakan suatu karya tari dimulai dari awal tari dengan garis pemikiran dari segi penonton dan dari itu gagasan melejit kesegala arah sementara keseluruhannya mencakup menjadi suatu ide, dan ide tersebut dituangkan ke dalam motif gerak awal hingga akhir.

Pada tari Kain memiliki rangkaian gerak dari awal hingga akhir yang di awali dengan ragam gerak, dimana gerakan awal dalam ragam gerak tari kain yaitu: 1. Melayang berdiri dilakuakn dalam keadaan berdiri, 2. Ngeliuk, 3. Hormat, 4. Melenggok badan kanan, 5.Ngeliuk, 6.Melenggok Badan Kiri, 7.Ngeliuk,8. Melenggok Kain kana, 9. Ngeliuk, 10. Melenggok kain kiri, 11. Ngeliuk, 12. Nampi kana, 13. Ngeliuk, 14. Nampi kiri,dinama gerakan tersebut dilakukan dengan berdiri. Ragam gerak tengah pada tari Kain yakni: 15. Ngeliuk duduk, 16. Melenggok badan duduk kanan, ,17. Melenggok badan duduk kiri, 18. Melenggok kain duduk kana, 19. Melenggok kain kiri.

Pada bagian akhir dari tari Kain yakni:20. Ngeliuk berdiri, 21. Hormat, 22. Melayang keluar. Dimana penari keluar dari arena pentas dan mempersikalan tamu masuk. Setiap ragamnya dihubungkan dengan gerak Ngeliuk sebagai transisi yang melekat, sehingga rangkaian dari tari Kain tersebut dapat tersusun secara utuh.Rangkaian di dalam suatu tarian sangant dibutuhkan untuk mengetahui urutan atau susunan di dalam gerak sehingga gerak yang ditampilkan menjadi baik oleh karena itu rangkaian dari tari Kain ini memiliki rangkaian yang baik dan tidak mengalami kekakuan gerak yang telah di rangkai.

\section{Perbandingan}

Teori Y. Sumandiyo Hadi tidak menjelaskan secara rinci tentang prinsip perbandingan namun hanya menjelaskan bahwa prinsip perbandingan merupakan salah satu dari prinsip bentuk gerak. Oleh karena itu peneliti menyimpulkan bahwa konsep perbandingan dalam bentuk gerak tari Kain tidak dilakukan atau dianalisis.

\section{Klimaks}

Klimaks tampilan sebagai percikan bunga api, dan terjadi melalui penuangan pameran artistik, keterampilan dan keindahan ide susunan gerak penata tari yang terbentuk sedemikian rupa dan mampu menimbulkn daya pikat penonton. Di segala kejadian bila betul-betul menginginkan untuk mencapai klimaks, maka klimaks harus nampak menonjol (Smith, 2016:48). Klimaks sangat erat hubungannya dalam mempertimbangakan rangkaian atau kontinyuitas yang telah dibicarakan sebelumnya. Dalam sebuah tarian atau koreografi selalu ada permulaan, "berjalan" atau "berkembang", dan ada "penyelesaian". "Klimaks" dinikmati sebagai titik puncak dari perkembangan, serta memberi artian dari kehadiran "permulaan", "perkembangan", dan akhir atau "penyelesaian" (Hadi, 2007:28-29). Klimaks sangat dibutuhkan dalam sebuah garapan tari agar karya tari tersebut memiliki kekuatan dan daya pemikat. Tanpa klimaks maka karya tari tersebut akan 
sangat monoton karena hanya menyajikan gerakan-gerakan saja (Rochayati Dkk, 2016:52).

Klimaks merupakan bagian yang paling menonjol atau intisari dari keseluruhan garapan tari. Klimaks dimaksudkan sebagai bagian yang terpenting karena dengan adanya klimaks baik penata tari, penonton, atau penikmat seni lainnya dapat atau mampu menyerap maksud dan tujuan dari suatu sajian karya tari tersebut. Klimaks juga merupakan bagian yang paling menonjol dari keseluruhan garapan tari. Pada tari Kain, klimaks terdapat pada akhir tarian yakni pada saat penari melakukan gerak Ngeliuk Berdiri atau perpindahan gerak dari duduk menuju gerak berdiri, lalu diikuti dengan gerakan Hormat dan gerakan Melayang Keluar yang mana gerakan ini mempersilahkan tamu untuk memasuki suatu acara.

Klimaks merupakan titik puncak dari suatu tarian sehingga penonton dapat memahami makna atau kesan yang terkadung di dalam tarian tersbut. Tari Kain terdapat klimaks di dalamnya dan dapat dilihat pada ragam gerak Ngeliuk Berdiri dan diikui dengan gerak Hormat, Melayang Keluar, atau gerakan ini gerakan mempersilahkan tamu memasuki acara yang datang di Kabupaten Musi Rawas.

\section{SIMPULAN}

Tari Kain merupakan tari tradisional yang pada masanya berfungsi untuk menyambut tamu Laki-laki yang datang dan di sambut oleh penari Perempuan. Tari Kain saat ini sudah jarang ditarikan karena kurangnya permintaan bahkan tidak ada lagi permintaan dari pemerintah untuk menunjukan eksistensi tari Kain ini. Tari Kain dibawakan oleh satu penari, dimana memang pada masanya tarian ini di tarikan oleh satu orang penar Perempuan untuk menyambut tamu Lakilaki.

Setelah lama tari Kain ini berkembang dan Lilian selaku penari dan salah satu yang fase dalam ragam gerak tari Kain. Tari Kain ini bisa ditarikan lebih dari satu orang jika tempatnya memadai, dan pernah juga tarian ini ditarikan oleh dua orang. Mengapa tari Kain ini dikatakan tari Kain karena pada saat pentas penari dalam menyambut tamu itu menggunakan Kain sebagai properti dan simbol bahwa setiap tamu yang datang di Kabupaten Musi Rawas ini diberikan Kain, makaitu Kainsendiri menjadi properti atau simbol. Kain sebagai simbol, karena adanya suatu kebiasaan dimana di daerah-daerah dan di dusun-dusun dari dulu hingga sekarang setiap tamu Laki-laki yang datang pasti akan mendapatkan Kain, sebagai penghormatan kepada tamu yang datang dan juga menyambut tamu yang datang disuatu acara.

Untuk mengetahui bentuk gerak tari Kain, penelitian meggunakan penelitian dekriptif kualitatif yakitu menentukan bagian-bagian gerak yang kemudian dianalisis sehingga gerak yang tersusun sebagai kesatuan yang utuh. Peneliti menggunakan teori prinsip bentuk Y.Sumandiyo Hadi yang terdiri dari tujuh prinsip bentuk yakitu kesatuan, variasi, repetisi, transisi, rangkaian, perbandingan, dan klimaks dalam hal memahami bentuk gerak tari Kain. 
Berdasarkan hasil penelitian yang dilakukan, maka hasil yang diperoleh dalam penggunaan teori prinsi bentuk oleh Y.Sumandiyo Hadi bahwa bentuk bentuk gerak tari Kain memiliki tujuh prinsip bentuk gerak yang telah dapat digunakan dan diaplikasikan dengan baik.
Hasil penelitian dilakukan dengan menentukan bentuk gerak yang ada dianalisa dan dipahami dengan pengaplikasian teori yang digunakan sehingga diketahui bahwa bentuk gerak tari Kain yang tersusun menjadi satu kesatuan yang utuh.

\section{DAFTAR PUSTAKA}

Fitriani, S. (Edisi 2, 2018). Analisis Bentk Gerak Tari Turak Sanggar Studio Ligga Kota Lubuklinggau. Dalam sitakara: Pendidikan Seni dan Seni.

Hadi, Y. (2016). Koreografi Bentuk Teks Isi. Yogyakarta: Cipta Media.

(2018). Revitalisasi Tari Tradisional. Yogyakarta: Cipta Medika. (2007). Kajian Tari Teks Dan Konteks. Yogyakarta: Pustaka Book Publisher.

Hera, T. (Edisi 2, 2016). Makna Gerak Tari Gending Sriwijaya di Sanggar Dinda Bestari Kota Palembang. dalam sitakara: Pendidikan Seni dan Seni.

Moleong, L. J. (2017). Metodelogi Penelitian Kualitatif. Bandug : PT Remaja Rosdakarya.

Paputri, L. (2019). Analisis Bentuk Gerak Tari Putri Berias Di Sanggar Studio Lingga Kota Lubuklinggau. (online), https://jurnal.univpgri-palembang.ac.id/index.php/sitakara/article/download/2340/2154, (diakses 20 Maret 2019)

Robert Budi Laksana, S. M. (2017). Pengetahuan Dasar Kesenian. Depok: PT Rajarafindo Persada.

Rochayati, R. (2019). Bentuk Gerak Tari Serimpi Kadang Premati Sebagai Materi Pembelajaran Pada Mata Kuliah Sejarah Dan Analisis Tari di Universitas

PGRIPalembang,(Online), https://jurnal.univpgripalembang.ac.id/index.php/sitakara/article/download 12345/2159, (diakses pada 3 Mei 2019)

..(2017). Menuju Kelas Koreografi. Palembang: Komunitas Lumbung Kreatif.

.(2014). Sejarah Analisis Tari. Palembang: Komunitas Titik Awal.

Rohidi, T. R. (2011). Metodologi Penelitian Seni. Semarang: Cipta Prima Nusantara.

Sihana, H. d. (2002). Metode Penelitian Kualitatif Perspektif Mikro. Insan Cendikia.

Sitakara. (2018). Jurnal Pendidikan Seni dan Seni. Universitas PGRI Palembang: Palembang.

Smith, J. (1985). Komposisi Tari : Sebuah Pertunjukan Praktis Bagi Guru. Yogyakarta: Ikalasti.

Sugiyono. (2016). Memahami Penelitian Kualitatif . Bandung: CV Alvabeta. (2009). Metode Penelitian Kuantitatif Kualitatif dan R\&D. Bandung: Alvabeta.

Widaryanto, F. (2005). Kritik Tari gaya, struktur, dan makna. Bandung: Kelir. (2011). Antropologi Tari. Yogyakarta: ISI Yogyakarta. 
